\title{
A two-year field study with transgenic Bacillus thuringiensis maize: Effects on soil microorganisms
}

\author{
Adília P. Oliveira ${ }^{a, *}$, Maria E. Pampulha $a^{a}$, James P. Bennett ${ }^{a, b}$ \\ aDepartamento de Botânica e Engenharia Biológica, Instituto Superior de Agronomia, Universidade Técnica de Lisboa (UTLisbon), Tapada da \\ Ajuda, 1349-017 Lisboa, Portugal \\ ${ }^{\mathrm{b}}$ Nelson Institute for Environmental Studies, University of Wisconsin, Madison, Wisconsin 53706, USA
}

\section{A R T I C L E I N F O}

Article history:

Received 30 October 2007

Received in revised form 4 April 2008

Accepted 30 May 2008

Available online 24 July 2008

\section{Keywords:}

Bt maize

Culturable soil microbiota

Dehydrogenase activity

Nitrogenase activity

ATP content

\begin{abstract}
A B S T R A C T
We evaluated the changes of some soil microbiological characteristics due to the use of transgenic maize expressing Bacillus thuringiensis (Bt) toxin. A two-year field experiment was conducted (2003 and 2004). Two lines of transgenic Bt maize that express the Cry1 Ab protein (event 176 and MON 810) and their near-isogenic non-Bt lines were used. Rhizosphere and non-rhizosphere soils were collected and measurements were performed during the maize cultural cycle and immediately at pre-harvest. Key soil microbiological parameters measured included the numbers of culturable aerobic bacteria, including actinomycetes, and fungi, the activity of dehydrogenase and nitrogenase enzymes and ATP content.

There were clear seasonal effects in the microbial parameters as evidenced by the consistent changes in sampling dates across the two years. Differences in the measured variables were also observed between rhizosphere and non-rhizosphere soils. However, under our field conditions, the presence of Bt maize did not cause, in a general way, changes in the microbial populations of the soil or in the activity of the microbial community.
\end{abstract}

(c) 2008 Elsevier B.V. All rights reserved.

\section{Introduction}

The insertion into plants of genes from Bacillus thuringiensis (Bt) that code for the production of insecticidal toxins (Cry proteins) reduces many problems associated with the use of chemical pesticides, as the toxins are produced continuously within these plants. However, the insecticidal protein, Cry $1 \mathrm{Ab}$, from $\mathrm{Bt}$ maize is introduced into soil primarily in root exudates (Saxena et al., 1999; Saxena and Stotzky, 2000) and also by incorporating plant residues after harvesting the crops (Tapp and Stotzky, 1998; Zwahlen et al., 2003). In vitro and in situ studies indicated that the Cry $1 \mathrm{Ab}$ protein was also present in the rhizosphere soil of field-grown Bt maize plants throughout their growth and several months after their death (Saxena and Stotzky, 2000). Although most Bt Cry proteins have high specificity, their effects on non-target organisms have not been fully evaluated.
Under laboratory conditions, no effect of the Cry1 $\mathrm{Ab}$ protein was found on collembolans (Sims and Martin, 1997; Heckmann et al., 2006), isopods (Escher et al., 2000), protozoa, nematodes, fungi, bacteria, algae, or earthworms (Saxena and Stotzky, 2001; Koskella and Stotzky, 2002; Baumgarte and Tebbe, 2005; Vercesi et al., 2006).

Other studies have examined the effects of Bt crops on soil ecosystem functions, such as residue decomposition. Most of these studies have compared the decomposition of Bt and non-Bt plant residues. Hopkins and Gregorich (2003) did not observe any detectable difference in the decomposition of plant material from Bt and non-Bt maize. Accordingly, Flores et al. (2005) found that numbers of culturable bacteria and fungi and the activities of representative enzymes involved in the degradation of plant biomass were not different between unamended soil or amended with biomass of Bt and non-Bt plants.

\footnotetext{
* Corresponding author. Tel.: +351 21 3653198; fax: +351 213635031.

E-mail address: adnpoliveira@isa.utl.pt (A.P. Oliveira).
} 
Some detrimental effects, such as mortality and reduced fecundity, have been observed in non-target invertebrates exposed to various Bt-producing strains (Mulla et al., 1982; Flexner et al., 1986). Studies of soil microbial and microfaunal communities also revealed differences in bacterial and fungal CLPP profiles (Blackwood and Buyer, 2004) and in nematodes population (Griffiths et al., 2005) under Bt maize cultivation. Donegan et al. (1995) observed effects of transgenic Bt cotton on both abundance and diversity of indigenous soil bacteria and fungi.

Biological and biochemical properties of soil have often been proposed as early and sensitive indicators of soil ecological stress or other environmental changes (Visser and Parkinson, 1992; Dick, 1994; Oliveira and Pampulha, 2006). Measurement of microbial populations in combination with their activity provides more sensitive information of the microbial changes than either activities or population analysis alone (Brookes, 1995).

Nitrogen fixation is performed by phylogenetically and physiologically diverse groups of prokaryotic organisms and is rapidly affected, positively or negatively, when environmental conditions are changed (Mårtensson, 1993). Dehydrogenase activity (DHA) and ATP content are also widely used in evaluating the metabolic activity of soil microorganisms (Bastida et al., 2007; Crecchio et al., 2007; Tejada et al., 2008).

The aim of this research was to evaluate changes in the soil microbiota due to the use of transgenic Bt maize. We performed a two-year experiment under field conditions with two hybrids of transgenic Bt maize and their nearisogenic lines. Soil microbiological parameters measured included numbers of culturable aerobic bacteria, including actinomycetes, and fungi, the activity of dehydrogenase and nitrogenase enzymes, and ATP content.

\section{Materials and methods}

\subsection{Site and plants}

The study was carried out on an experimental farm in the central region of Portugal. The soil is a well-drained sandy soil (pH, 6.2; organic carbon, $12 \mathrm{~g} \mathrm{~kg}^{-1}$; sand, $80.2 \%$; silt, 18.6\%; clay, $1.3 \%)$. The experiment was conducted in two successive years (2003 and 2004) in a large plot $(160 \mathrm{~m} \times 60 \mathrm{~m})$ where transgenic Bt or non-Bt maize had never been planted. This plot was subdivided into 4 sub-plots $(80 \mathrm{~m} \times 30 \mathrm{~m}$ each). Two varieties of transgenic Bt maize [CG 00256-176, Cry1Ab (Compa Cb), from
Syngenta and MON 810, Cry 1Ab (Elgina), from Pioneer] and their near-isogenic lines (Dracma and Cecilia, respectively) were used in this study. Each sub-plot was sown with a different maize line, under irrigated conditions. Soils were sampled from the 4 sub-plots, between 0 and $20 \mathrm{~cm}$ deep. The sub-plots were established in 2003 as part of a larger study examining the efficiency of the utilization of Bt maize in the control of Sesamia nonagrioides and Ostrinia nubilalis.

\subsection{Soil sampling}

Rhizosphere and non-rhizosphere soil samples were collected, in both years, 30 days after sowing (2003: middle June; 2004: beginning of June) and immediately at pre-harvest (2003: beginning of October; 2004: end of September).

Ten soil samples were collected from each sub-plot (5 rhizosphere samples and 5 non-rhizosphere samples). Nonrhizosphere soil was taken at a depth of $0-20 \mathrm{~cm}$. To obtain rhizosphere soil, root material with adhering soil was removed with a trowel and placed in a plastic bag. All visible plant debris was removed manually. Each soil sample was then sieved $(2 \mathrm{~mm})$, and stored at $4{ }^{\circ} \mathrm{C}$, in the dark, before analysis.

\subsection{Enumeration of bacteria, actinomycetes and saprophytic fungi}

Colony-forming units (CFU) of culturable heterotrophic bacteria, actinomycetes, and fungi, were determined by serial dilution and plating on selective media. Serial dilutions of soil samples (1 g fresh weight) were made with $1 / 4$ strength Ringers solution. Plate counts of culturally-viable bacteria were made on Tryptone Soya Agar (TSA, Oxoid) amended with $0.1 \mathrm{~g}$ of cycloheximide $\mathrm{l}^{-1}$. For fungi, the medium was Rose Bengal Agar (RB, Oxoid) amended with $30 \mathrm{mg}$ of streptomycin sulphate $\mathrm{l}^{-1}$. Actinomycetes were counted on Glycerol Casein Agar (Williams and Wellington, 1982) amended with $0.05 \mathrm{~g}$ of cycloheximide $\mathrm{l}^{-1}$. The plates were inoculated with $0.1 \mathrm{ml}$ of soil suspension and incubated at $25^{\circ} \mathrm{C}$ for 4-7 days for fungi and heterotrophic bacteria and for 10 days for actinomycetes. All the results are expressed on an oven-dry wt basis.

\subsection{Dehydrogenase activity}

Dehydrogenase activity (DHA) was determined by the method of Tabatabai (1982) using $1 \mathrm{ml}$ of a 3\% triphenyl tetrazolium chloride (TTC) solution per $20 \mathrm{~g}$ of soil (dry weight equivalent).

Table 1 - Example ANOVA for bacteria data

\begin{tabular}{|c|c|c|c|c|c|}
\hline Source of variation & Degrees of freedom & Sum of squares & Mean squares & F & Probability \\
\hline Year (Y) & 1 & 9211.2 & 9211.2 & 201.4 & 0.0008 \\
\hline Maize (M) & 3 & 457.9 & 152.6 & 3.3 & 0.1743 \\
\hline Year $\times$ maize & 3 & 137.2 & 45.7 & 6.3 & 0.0005 \\
\hline Sample date $(\mathrm{Y} \times \mathrm{M})$ & 8 & 1197.7 & 149.7 & 2.7 & 0.0897 \\
\hline Rhizosphere/non-rhizosphere soil $(\mathrm{Y} \times \mathrm{M})$ & 8 & 3975.6 & 497.0 & 9.0 & 0.0027 \\
\hline Sample date $(\mathrm{Y} \times \mathrm{M}) \times$ rhizosphere/non-r $(\mathrm{Y} \times \mathrm{M})$ & 8 & 441.2 & 55.2 & 7.6 & 0.0000 \\
\hline Error & 128 & 928.7 & 7.3 & & \\
\hline Total & 159 & & & & \\
\hline
\end{tabular}

Significant sources of variation at the 0.05 probability level are in bold font. 
Table 2-Effects of $\mathrm{Bt}$ maize on heterotrophic aerobic bacteria (mean CFU $\times 10^{6} \mathrm{~g}^{-1}$ dry soil)

\begin{tabular}{|c|c|c|c|c|c|}
\hline & $\begin{array}{l}\text { Elgina } \\
(\mathrm{t})\end{array}$ & Cecilia & $\underset{(t)}{C}$ & Dracma & Average \\
\hline Sowing & 18.94 & 15.95 & 11.33 & 11.12 & 14.33 \\
\hline Rhizosphere & 23.70 & 20.65 & 13.70 & 13.52 & 17.89 \\
\hline $\begin{array}{l}\text { Non- } \\
\text { rhizosphere }\end{array}$ & 14.17 & 11.25 & 8.95 & 8.71 & 10.77 \\
\hline Harvest & 15.94 & 18.45 & 17.66 & 15.94 & 16.99 \\
\hline Rhizosphere & 20.43 & 26.58 & 22.93 & 21.80 & 22.94 \\
\hline $\begin{array}{l}\text { Non- } \\
\text { rhizosphere }\end{array}$ & 11.44 & 10.32 & 12.38 & 10.07 & 11.05 \\
\hline Average & 17.44 & 17.20 & 14.49 & 13.53 & 15.66 \\
\hline Tukey's HSD & $\mathrm{a}$ & a & b & $\mathrm{b}$ & \\
\hline
\end{tabular}

$(t)=$ transgenic line. Sowing and Harvest refer to the two sampling times, while Rhizosphere and Non-rhizosphere refer to the two soil sampling areas, which were nested within the sampling times.

Year is not presented because it is a block term. Marginal averages in column 6 in bold font were significantly different as determined by ANOVA, while those in the last row were determined by Tukey's HSD test. In the latter, means followed by different letters are significantly different at the 0.05 probability level.

TTC is converted to triphenyl formazan (TPF), a red dye that is detected using a spectrophotometer (485 $\mathrm{nm}$ ) after incubation $\left(24 \mathrm{~h}\right.$ at $\left.37^{\circ} \mathrm{C}\right)$.

Results were expressed in $\mu \mathrm{g} \mathrm{TPF} \cdot \mathrm{g}^{-1}$ of dry soil $24 \mathrm{~h}^{-1}$ and were calculated from spectrophotometer calibration in the range of $0-500 \mu \mathrm{g} \mathrm{TPF} \cdot \mathrm{g}^{-1}$ of dry soil.

\subsection{Nitrogenase activity}

Nitrogenase activity was measured as acetylene reduction activity (ARA). Soil samples corresponding to $20 \mathrm{~g}$ of dry weight were placed in serum bottles, and $5 \mathrm{ml}$ of Combinated Carbon (CC) medium (Rennie, 1981) was added. After a preincubation period of $24 \mathrm{~h}$ at $25^{\circ} \mathrm{C}$, samples were incubated for $24 \mathrm{~h}$ at $25{ }^{\circ} \mathrm{C}$ with $10 \%\left(\mathrm{vv}^{-1}\right)$ acetylene $\left(\mathrm{C}_{2} \mathrm{H}_{2}\right)$. Gas samples were obtained from the bottles with gas-tight syringes and analysed for ethylene $\left(\mathrm{C}_{2} \mathrm{H}_{4}\right)$ using a gas chromatograph Varian 3800GC (Varian Analytical Instruments, Mitchell Drive, Walnut Creek, USA), fitted with a $1 \mathrm{~m} \times 1 / 8^{\prime \prime}$ column packed with Porapak $\mathrm{T}(80-100$ mesh) and a flame-ionization detector (FID). Corrections were made for traces of $\mathrm{C}_{2} \mathrm{H}_{4}$ in the

Table 3-Effects of Bt maize on actinomycetes (mean CFU $\times 10^{5} \mathrm{~g}^{-1}$ dry soil)

\begin{tabular}{|c|c|c|c|c|c|}
\hline & $\begin{array}{l}\text { Elgina } \\
(\mathrm{t})\end{array}$ & Cecilia & $\begin{array}{c}\text { Compa } \\
(\mathrm{t})\end{array}$ & Dracma & Average \\
\hline Sowing & 11.47 & 14.90 & 8.63 & 8.84 & 10.96 \\
\hline Rhizosphere & 9.74 & 13.35 & 6.35 & 7.70 & 9.29 \\
\hline $\begin{array}{l}\text { Non- } \\
\text { rhizosphere }\end{array}$ & 13.19 & 16.44 & 10.91 & 9.97 & 12.63 \\
\hline Harvest & 21.70 & 21.75 & 23.50 & 21.60 & 22.14 \\
\hline Rhizosphere & 24.30 & 24.80 & 23.80 & 21.10 & 23.50 \\
\hline $\begin{array}{l}\text { Non- } \\
\text { rhizosphere }\end{array}$ & 19.10 & 18.70 & 23.20 & 22.10 & 20.78 \\
\hline Average & 16.58 & 18.32 & 16.07 & 15.22 & 16.55 \\
\hline Tukey's HSD & $\mathrm{b}$ & a & b & b & \\
\hline
\end{tabular}

$(t)=$ transgenic line. See Table 2 for explanation.
Table 4 - Effects of Bt maize on fungi (mean CFU $\times 10^{4} \mathrm{~g}^{-1}$ dry soil)

\begin{tabular}{lccccc} 
& $\begin{array}{c}\text { Elgina } \\
(\mathrm{t})\end{array}$ & $\begin{array}{c}\text { Cecilia } \\
\text { Sowing }\end{array}$ & $\begin{array}{c}\text { Compa } \\
(\mathrm{t})\end{array}$ & Dracma & Average \\
\hline Rhizosphere & 12.39 & 8.27 & 10.40 & 13.40 & 11.12 \\
$\quad$ Non- & 14.64 & 9.70 & 8.50 & 11.75 & 9.27 \\
rhizosphere & & & 12.30 & 15.05 & 12.96 \\
Harvest & 22.42 & 21.38 & 13.57 & 14.29 & 17.91 \\
$\quad$ Rhizosphere & 30.08 & 27.09 & 9.62 & 11.45 & 19.56 \\
$\quad$ Non- & 14.76 & 15.67 & 17.51 & 17.13 & 16.27 \\
$\begin{array}{l}\text { rhizosphere } \\
\text { Average }\end{array}$ & 17.41 & 14.83 & 11.98 & 13.85 & 14.51 \\
Tukey's HSD & $\mathrm{a}$ & $\mathrm{b}$ & $\mathrm{c}$ & $\mathrm{b}$ & \\
\hline
\end{tabular}

$(\mathrm{t})=$ transgenic line. See Table 2 for explanation.

$\mathrm{C}_{2} \mathrm{H}_{2}$. The results, the means of 10 replicate samples, were expressed on the basis of dry weight of soil.

\subsection{ATP content}

The ATP content in soil was determined according to published methods (Oades and Jenkinson, 1979; Tate and Jenkinson, 1982), with some modifications. Fresh soil (5 g) was suspended in $50 \mathrm{ml}$ of extracting solution [0.5 M trichloroacetic acid (TCA) and $0.25 \mathrm{M} \mathrm{Na}_{2} \mathrm{PO}_{4}$ ]. After stirring, soil samples were sonicated for $3 \mathrm{~min}$., and the suspensions were centrifuged at $1500 \mathrm{~g}$ for $5 \mathrm{~min}$ at $4{ }^{\circ} \mathrm{C}$. Aliquots of $50 \mu \mathrm{l}$ were taken from the supernatant and were transferred into polystyrene tubes, mixed with $4.95 \mathrm{ml}$ of EDTA-Tris acetate buffer (0.1 M Tris, $2 \mathrm{mM}$ EDTA), $\mathrm{pH} 7.75$, and vortexed for $10 \mathrm{~s}$. Aliquots of $150 \mu \mathrm{l}$ were tested for ATP by adding them to a buffered luciferin-luciferase solution.

The radiation emission of the mixtures was measured with a TD-20/20 Luminometer (Turner Designs, Sunnyvale, CA, USA). The estimate of the soil ATP content was done in triplicate. Autoclaved soil extracts were used to obtain blank values. Counts over a $10 \mathrm{~s}$ integration time were compared with a standard curve of ATP.

\subsection{Experimental design and statistics}

This study was designed as a randomized complete block, multi-factorial, double-nested with sub-sampling experiment.

Table 5-Effects of Bt maize on dehydrogenase activity (mean $\mu \mathrm{g}$ TPF.g ${ }^{-1} 24 \mathrm{~h}^{-1}$ dry soil)

\begin{tabular}{lccccc} 
& $\begin{array}{c}\text { Elgina } \\
(\mathrm{t})\end{array}$ & Cecilia & $\begin{array}{c}\text { Compa } \\
(\mathrm{t})\end{array}$ & Dracma & Average \\
\hline Sowing & 13.45 & 15.85 & 19.55 & 16.70 & 16.39 \\
$\quad$ Rhizosphere & 16.10 & 17.60 & 22.50 & 20.20 & 19.10 \\
$\quad$ Non- & 10.80 & 14.10 & 16.60 & 13.20 & 13.68 \\
rhizosphere & & & & & \\
Harvest & 43.40 & 38.70 & 27.80 & 28.05 & 34.49 \\
$\quad$ Rhizosphere & 46.60 & 48.00 & 33.20 & 36.10 & 40.98 \\
$\quad \begin{array}{l}\text { Non- } \\
\text { rhizosphere }\end{array}$ & 40.20 & 29.40 & 22.40 & 20.00 & 28.00 \\
$\begin{array}{l}\text { Average } \\
\text { Tukey's HSD }\end{array}$ & $\mathrm{a}$ & $\mathrm{a}$ & $\mathrm{b}$ & $\mathrm{b}$ & \\
\hline
\end{tabular}

$(t)=$ transgenic line. See Table 2 for explanation. 
The block treatment was the two years of sampling and the four maize lines were the main source of variation. The interaction of blocks and maize lines was used for significance testing of the blocks and maize lines. Nested within these were the two sampling dates and the rhizosphere/non-rhizosphere soils, each with two levels. These treatments were tested with their interaction mean squares, and the latter with the residual error from the sub-sampling. These analyses of variance (ANOVAs) were performed in two steps: the calculations of the mean squares were done first with JMP 6, and the F tests then calculated by hand. Because the differences among the maize lines were the principal subject of interest, the means were subsequently tested a posteriori to the ANOVAs using Tukey's HSD mean separation test at the 0.05 probability level.

\section{Results}

Six ANOVAs were calculated to test for significant differences among the treatment means. Given the complexity of the ANOVA model, an example is given in Table 1 for the bacteria data. The remaining five ANOVAs are not presented. Maize line was not a significant source of variation in any of the six ANOVAs. Year, which is the block term, was significant in four of the six ANOVAs, which then resulted in the year by maize line interaction source of variation being significant for all six variables. Therefore the interaction term was used to test the maize line source of variation. It is the only variation at the same scale that can be used in the $F$ test. In general, values for the different microbiological parameters under analysis were higher in Year 2, which were likely related to differences in weather conditions.

Sampling date was significant in three of the ANOVAs, while rhizosphere/non-rhizosphere soils were significant in only two ANOVAs.

The numbers of culturable heterotrophic aerobic bacteria (Table 2) and actinomycetes (Table 3) showed no statistically or biologically significant differences between soils planted with Bt or non-Bt maize. Some significant differences were observed in the abundance of saprophytic fungi (Table 4). Fungal populations were lower 30 days after sowing in soils with Compa $\mathrm{Cb}$ transgenic maize when compared with its

Table 6-Effects of Bt maize on soil ATP content (mean $\mathrm{ng} \cdot \mathrm{g}^{-1}$ dry soil)

\begin{tabular}{lccccc} 
& $\begin{array}{c}\text { Elgina } \\
(\mathrm{t})\end{array}$ & \multicolumn{1}{c}{ Cecilia } & $\begin{array}{c}\text { Compa } \\
(\mathrm{t})\end{array}$ & Dracma & Average \\
\hline Sowing & 270.70 & 239.25 & 246.25 & 281.75 & 259.49 \\
$\quad$ Rhizosphere & 298.90 & 285.50 & 287.50 & 360.00 & 307.98 \\
$\quad$ Non- & 242.50 & 193.00 & 205.00 & 203.50 & 211.00 \\
rhizosphere & & & & & \\
Harvest & 357.00 & 427.50 & 467.50 & 421.50 & 418.38 \\
$\quad$ Rhizosphere & 470.50 & 544.00 & 565.00 & 514.00 & 523.38 \\
$\quad$ Non- & 243.50 & 311.00 & 370.00 & 329.00 & 313.38 \\
$\begin{array}{l}\text { rhizosphere } \\
\text { Average }\end{array}$ & 313.85 & 333.38 & 356.88 & 351.63 & 338.93 \\
Tukey's HSD & $\mathrm{b}$ & $\mathrm{ab}$ & $\mathrm{a}$ & $\mathrm{a}$ & \\
\hline
\end{tabular}

$(t)=$ transgenic line. See Table 2 for explanation.
Table 7 - Effects of Bt maize on nitrogenase activity (mean nmoles $\mathrm{C}_{2} \mathrm{H}_{4} \cdot \mathrm{g}^{-1} \cdot 24 \mathrm{~h}^{-1}$ dry soil)

\begin{tabular}{lllllr} 
& $\begin{array}{c}\text { Elgina } \\
(\mathrm{t})\end{array}$ & \multicolumn{1}{c}{ Cecilia } & $\begin{array}{c}\text { Compa } \\
(\mathrm{t})\end{array}$ & Dracma & Average \\
\hline Sowing & 11.75 & 9.95 & 12.25 & 13.95 & 11.98 \\
$\quad$ Rhizosphere & 18.40 & 14.10 & 19.40 & 22.00 & 18.48 \\
$\quad$ Non- & 5.10 & 5.80 & 5.10 & 5.90 & 5.48 \\
rhizosphere & & & & & \\
Harvest & 89.85 & 95.00 & 235.75 & 208.75 & 157.34 \\
$\quad$ Rhizosphere & 111.90 & 168.70 & 422.80 & 379.00 & 270.60 \\
$\quad$ Non- & 67.80 & 21.30 & 48.70 & 38.50 & 44.08 \\
rhizosphere & & & & & \\
$\begin{array}{l}\text { Average } \\
\text { Tukey's HSD }\end{array}$ & 50.80 & 52.48 & 124.00 & 111.35 & 84.66 \\
\hline
\end{tabular}

$(t)=$ transgenic line. See Table 2 for explanation.

isogenic line Dracma. Maize lines did have statistically different fungal population means, but they were not biologically meaningful. This effect did not persist at pre-harvest date, where values did not show significant differences. Between sampling dates numbers of these three major soil microbial groups were higher at pre-harvest date. Large number of heterotrophic bacteria was also detected in the rhizosphere soil. In contrast, actinomycetes and fungi were not, in general, stimulated in the rhizosphere.

The variations in soil DHA activity and ATP content are shown in Tables 5 and 6 , respectively. The presence of Bt maize did not affect, in a general way, these soil parameters. The values in rhizosphere soil were higher, in general agreement with the microbial counts.

A marked influence of the presence of maize roots was detected in the nitrogenase activity (Table 7), as values were significantly higher at the pre-harvest date in the rhizosphere soil. However, the presence of transgenic maize lines did not significantly affect nitrogenase activity.

In spite of some individual cases of reduced populations under Bt compared with non-Bt maize, these reductions were transient and did not persist between sampling times.

\section{Discussion}

We evaluated the effects of Bt maize under typical field conditions, within large plots. The results indicated that $\mathrm{Bt}$ maize did not cause significant effects on the variables measured. Occasional significant differences did not persist. Our field-based results are consistent with other experiments (Donegan et al., 1995; Saxena and Stotzky 2001; Devare et al., 2007) indicating that the transgenic corn had no discernable effect on the bacterial community. In a microcosm experiment with Bt transgenic cotton leaves, Donegan et al. (1995) observed that two of the three transgenic lines produced a significant but transient increase in the number of CFUs of culturable bacteria and fungi, and Saxena and Stotzky (2001) found that there were no significant differences in the CFUs of culturable bacteria, actinomycetes or fungi between soil amended with biomass of Bt-corn and non-Bt-corn after 45 days of incubation. Studies conducted by Wu et al (2004) on $\mathrm{Bt}$ rice (Cry1A) in China suggested that $\mathrm{Bt}$ rice had no 
negative effect on a range of soil microbial indicators. In contrast, some antagonistic effects of the Cry insecticidal protein on ammonification and nitrification have been reported (Visser et al., 1994), but other studies have shown no deleterious effects (Casida, 1989). Glare and O'Callaghan (2000) reported that many of the effects on microorganisms were short term and concluded that it was unlikely that there would be any lasting effects on soil microbial processes. In another study on Bt proteins, an experiment carried out under laboratory conditions to investigate the differences in the population of culturable microorganisms and the enzymatic activities between soils amended with straw of transgenic rice containing the Cry $1 \mathrm{Ab}$ gene and the isogenic non-transgenic rice showed no significant differences in the CFU of culturable bacteria, actinomycetes and fungi between the two soils (Weixiang et al., 2004).

We did observe some stimulatory rhizosphere effects on measured variables as compared to non-rhizosphere soil. These findings are in keeping with previous work demonstrating that increases in plant root exudation result in increased microbial activity (Swinnen, 1994; Ryan et al., 2001).

Among the many essential functions of the soil biota are microbially-mediated processes related to nutrient cycling, such as oxidation-reduction reactions and biological $\mathrm{N}_{2}$ fixation (Motavalli et al., 2004), but relatively little research has examined the effects of transgenic crops on these processes and functions in soil (O'Callaghan and Glare, 2001; Bruinsma et al., 2003). In this study some differences were observed in nitrogenase activity, namely between rhizosphere soil of Compa Cb and its near-isogenic line (Dracma), in year 1. $\mathrm{N}_{2}$-fixing activity also seemed to be more sensitive to changes in soil conditions, as ARA showed a marked increase in the rhizosphere when compared with the other microbiological parameters measured. There were clear seasonal effects on microbial biomass and activity in our field plots, as represented by the consistent changes in all measured variables across years and sampling dates. In year 1, most of microbiological parameters evaluated showed a severe reduction probably due to unusually dry season.

Because dehydrogenases are not active as extracellular enzymes in soil, independent of the parent microbial cell, the measurement of DHA is a good overall indicator of microbial activity. DHA has been used as an indicator of the microbiological activity in semi-arid Mediterranean soils (Garcia et al., 1994), in agricultural soils in Germany (Beyer et al., 1982), in Mediterranean soils during the dry and wet seasons (Quilchano and Marañón, 2002), and in soil management studies (Bergstrom et al., 1998). Differences in DHA could also be the result of differences in the composition of microbiota in stressed soil (Leirós et al., 2000). ATP is the most important and central coupling agent between exergonic and endergonic processes in all cells; in dead cells ATP is quickly degraded. Owing to its properties, ATP is proposed as a parameter for either estimating microbial activities or biomass in soil. Soil ATP is also closely related with other indices of biomass, e. g. C, N, etc. and can serve as an independent estimate of soil biomass content (Contin et al., 2001).

In the present study, an evaluation of DHA and ATP content in soils under Bt and non-Bt maize was undertaken. The values obtained for both soils (rhizosphere and non-rhizosphere) showed no significant differences.
Among the potential direct effects are changes in soil microbial activity due to differences in the amount and composition of root exudates. The insecticidal protein in root exudates binds rapidly to clay minerals and humic substances, which protect the protein from microbial degradation (Tapp et al., 1994; Crecchio and Stotzky, 1998; Saxena et al., 2002). The bound protein retains its insecticidal activity and has been observed to persist in soil up to 234 days (Saxena et al., 1999). Similar results on the persistence of the insecticidal protein of Bt cotton, but for shorter periods of time (up to 140 days), have also been reported (Palm et al., 1996). However, in a survey of the levels of Cry1Ac protein in soil samples of six fields with continuous Bt cotton for 3 to 6 years, Head et al. (2002) indicated that no detectable Cry1Ac protein or biological insecticidal activity was present in any of the fields. Tapp and Stotzky (1998) found that insecticidal activity was retained when the Cry protein was incubated in soil, but the amount of retention varied with the type of soil, probably because of differences in the clay mineral composition and the $\mathrm{pH}$ of the soils. Since clay content increases the retention of Cry proteins (Crecchio and Stotzky, 1998), the protein probably does not persist for a long period in our soil conditions since the soil under study was sandy and well drained. Although the Cry protein level has not been evaluated we can presume that if the Cry proteins do not bind on clays they are available to soil microbes and a short term effect on the microbial parameters under study could be expected, but such an effect was not observed for the first sampling date.

Our study over two years in the same plots suggested there were no cumulative effects of Bt maize, at least in the short term. The differences caused by growing Bt maize were not as large as those resulting from rhizosphere and seasonal changes indicating that the effect of Bt maize on soil microorganisms was within the normal variation expected in conventional agricultural systems.

\section{Acknowledgement}

This research was supported by Project AGRO 17, under AGRO Program - Medida 8 - Acção 8.1.

\section{R E F E R E N C E S}

Bastida F, Moreno JL, Hernandez T, Garcia C. Microbial activity in non-agricultural degraded soils exposed to semiarid climate. Sci Total Environ 2007;378:183-6.

Baumgarte S, Tebbe CC. Field studies on the environmental fate of the Cry1Ab Bt-toxin produced by transgenic maize (Mon810) and its effect on bacterial communities in the maize rhizosphere. Mol Ecol 2005;14:2539-51.

Bergstrom DW, Monreal CM, King DJ. Sensitivity of soil enzyme activity to conservation practices. Soil Sci Soc Am J 1998;62:1286-95.

Beyer L, Wachendorf C, Balzer FM, Balzer-Graf UR. The effect of soil texture and soil management on microbial biomass and soil enzyme activities in arable soils of Northwest Germany. Agrobiol Res 1982;45:276-83.

Blackwood CB, Buyer JS. Soil microbial communities associated with Bt and non-Bt corn in three soils. J Environ Qual 2004;33:832-6. 
Brookes PC. The use of microbial parameters in monitoring soil pollution by heavy metals. Biol Fertil Soils 1995;19:269-79.

Bruinsma M, Kowalchuck GA, van Veen JA. Effects of genetically modified plants on microbial communities and processes in soil. Biol Fertil Soils 2003;37:329-37.

Casida LE. Protozoan response to the addition of bacterial predators and other bacteria to soil. Appl Environ Microbiol 1989;55:1857-9.

Contin M, Todd MA, Brookes PC. The ATP concentration in the soil microbial biomass. Soil Biol Biochem 2001;33:701-4.

Crecchio C, Stotzky G. Insecticidal activity and biodegradation of the toxin from Bacillus thuringiensis subsp. kurstaki bound to humic acids in soil. Soil Biol Biochem 1998;30:463-70.

Crecchio C, Curci M, Pellegrino A, Riccioti P, Tursi N, Ruggiero P. Soil microbial dynamics and genetic diversity in soil under monoculture wheat grown in different long-term management systems. Soil Biol Biochem 2007;39:1391-400.

Devare M, Londoño LM, Thies JE. Neither transgenic Bt maize (MON863) nor tefluthrin insecticide adversely affect soil microbial activity or biomass: a 3-year field analysis. Soil Biol Biochem 2007;39:2038-47.

Dick RP. Soil enzyme activities as indicators of soil quality. In: Doran JW, Coleman DC, Bezdicek DF, Stewart BA, editors. Defining soil quality for a sustainable environment. Madison, WI: American Society of Agronomy; 1994. p. 107-24.

Donegan KK, Palm CJ, Fieland VJ, Porteous LA, Ganio LM, Schaller DL. Changes in levels, species and DNA fingerprints of soil microorganisms associated with cotton expressing the Bacillus thuringiensis var. kurstaki endotoxin. Appl Soil Ecol 1995;2:111-24.

Escher N, Käch B, Nentwig W. Decomposition of transgenic Bacillus thuringiensis maize by microorganisms and woodlice Porcelio scaber. Bas Appl Ecol 2000;1:161-9.

Flexner JL, Lighthart B, Croft BA. The effects of microbial pesticides on non-target, beneficial arthropods. Agric Ecosyst Environ 1986;16:203-56.

Flores S, Saxena D, Stotzky G. Transgenic Bt plants decompose less in soil than non-Bt plants. Soil Biol Biochem 2005;37:1073-82.

Garcia C, Hernandez T, Costa F. Microbial activity in soils under Mediterranean environmental conditions. Soil Biol Biochem 1994;26:1185-91.

Glare TR, O'Callaghan M. Bacillus thuringiensis. Biology, Ecology and Safety. Chichester: John Wiley \& Sons; 2000.

Griffiths BS, Caul S, Thompson J, Birch ANE, Scrimgeour C, Andersen MN, et al. A comparison of soil microbial community structure, protozoa and nematodes in field plots of conventional and genetically modified maize expressing the Bacillus thuringiensis Cry1Ab toxin. Plant Soil 2005;275:135-46.

Head G, Surber JB, Watson J, Martin JW, Duan JJ. No detection of Cry1Ac protein in soil after multiple years of transgenic Bt-cotton (Bollgard) use. Environ Entomol 2002;31:30-6.

Heckmann LH, Griffiths BS, Caul S, Thompson J, Pusztai-Carey M, Moar WJ, et al. Consequences for Protaphorura armata (Collembola: Onychiuridae) following exposure to genetically modified Bacillus thuringiensis (Bt) maize and non-Bt maize. Environ Pollut 2006;142:212-6.

Hopkins DW, Gregorich EG. Detection and decay of the Bt endotoxin in soil from a field trial with genetically modified maize. Eur J Soil Sci 2003;54:793-800.

Koskella J, Stotzky G. Larvicidal toxins from Bacillus thuringiensis subspp, kurstaki, morrisoni (strain tenebrionis), and israelensis have no microbicidal or microbiostatic activity against selected bacteria, fungi, and algae in vitro. Can J Microbiol 2002;48:262-7.

Leirós MC, Trasar-Cepeda C, Seoane S, Gil-Sotres F. Biochemical properties of acid soils under clímax vegetation (Atlantic oakwood) in an area of the European temperate-humid zone (Galicia, NW Spain): general parameters. Soil Biol Biochem 2000;32:733-45.
Mårtensson AM. Use of heterotrophic and cyanobacterial nitrogen fixation to study the impact of anthropogenic substances on soil biological processes. Bull Environ Contam Toxicol 1993;50:466-73.

Motavalli PP, Kremer RJ, Fang M, Means NE. Impact of genetically modified crops and their management on soil microbially mediated plant nutrient transformations. J Environ Qual 2004;33:816-24.

Mulla MS, Federichi BA, Darwazeh HA. Larvicidal effect of Bacillus thuringiensis serotype $\mathrm{H}-14$ against stagnant-water mosquitoes and its effect on non target organisms. Environ Entomol 1982;11:788-95.

O'Callaghan M, Glare TR. Impacts of transgenic plants and microorganisms on soil biota. N Z Plant Protection 2001;54:105-10.

Oades JM, Jenkinson DS. Adenosine triphosphate content of the soil microbial biomass. Soil Biol Biochem 1979;11:201-4.

Oliveira A, Pampulha ME. Effects of long-term heavy metal contamination on soil microbial characteristics. J Biosci Bioeng 2006;102(3):157-61.

Palm CJ, Shaller DL, Donegan KK, Seidler RJ. Persistence in soil of transgenic plant produced Bacillus thuringiensis var. kurstaki 6-endotoxin. Can J Microbiol 1996;42:1258-62.

Quilchano C, Marañón T. Dehydrogenase activity in Mediterranean forest soils. Biol Fertil Soils 2002;35:102-7.

Ryan PR, Delhaize E, Jones DL. Function and mechanism of organic anion exudation from plant roots. Annu Rev Plant Physiol Plant Mol Biol 2001;52:527-60.

Rennie RJ. A single medium for the isolation of acetylene-reducing (dinitrogen-fixing) bacteria from soils. Can J Microbiol 1981;27:8-14.

Saxena D, Stotzky G. Insecticidal toxin from Bacillus thuringiensis is released from roots of transgenic Bt corn in vitro and in situ. FEMS Microbiol Ecol 2000;33:35-9.

Saxena D, Stotzky G. Bacillus thuringiensis (Bt) toxin released from root exudates and biomass of Bt corn has no apparent effect on earthworms, nematodes, protozoa, bacteria and fungi in soil. Soil Biol Biochem 2001;33:1225-30.

Saxena D, Flores S, Stotzky G. Insecticidal toxin in root exudates from Bt corn. Nature 1999;402:480.

Saxena D, Flores S, Stotzky G. Bt toxin is released in root exudates from 12 transgenic corn hybrids representing three transformation events. Soil Biol Biochem 2002;34:133-7.

Sims SR, Martin JW. Effects of the Bacillus thuringiensis insecticidal proteins Cry1A(b), Cry1A(c), CryIIA and CryIIIA on Folsomia candida and Xenylla grisea (Insecta. Collembola). Pedobiologia 1997;41:412-6.

Swinnen J. Evaluation of the use of a model rhizodeposition technique to separate root and microbial respiration in soil. Plant Soil 1994;165:89-101.

Tabatabai MA. Soil enzymes. In: Page AL, editor. Methods of soil analysis, Part 2. Chemical and microbiological properties. 2nd ed. Madison, WI: American Society of Agronomy; 1982. p. 903-4.

Tapp H, Stotzky G. Persistence on the insecticidal toxin from Bacillus thuringiensis subsp. kurstaki in soil. Soil Biol Biochem 1998;30:471-6.

Tapp H, Calamai L, Stotzky G. Adsorption and binding of the insecticidal proteins from Bacillus thuringiensis subsp. kurstaki and subsp. tenebrionis on clay minerals. Soil Biol Biochem 1994;26:663-79.

Tate KR, Jenkinson DS. Adenosine triphosphate measurement in soil: an improved method. Soil Biol Biochem 1982;14:331-5.

Tejada M, Gonzalez JL, Garcia-Martinez AM, Parrado J. Effects of different green manures on soil biological properties and maize yield. Bioresour Technol 2008;99:1758-67.

Vercesi ML, Krogh PH, Holmstrup M. Can Bacillus thuringiensis (Bt) corn residues and Bt-corn plants affect life-history traits in the earthworm Aporrectodea caliginosa? Appl Soil Ecol 2006;32:180-7. 
Visser S, Parkinson D. Soil biological criteria as indicators of soil quality: soil microorganisms. Am J Altern Agric 1992;7:33-7.

Visser S, Addison JA, Holmes SB. Effects of Dipel@ 176, a Bacillus thuringiensis subsp. kurstaki (B.t.k.) formulation, on the soil microflora and the fate of B.t.k. in an acid forest soil: a laboratory study. Can J For Res 1994;24:462-71.

Wei-xiang W, Qing-fu Y, Hang M, Xue-jun D, Wen-ming J. Bt transgenic rice straw affects the culturable microbiota and dehydrogenase and phosphatase activities in a flooded paddy soil. Soil Biol Biochem 2004;36:289-95.

Wu WX, Ye QF, Min H. Effect of straws from Bt-transgenic rice on selected biological activities in water-flooded soil. Eur J Soil Biol 2004;40:15-22.
Williams ST, Wellington EMH. Actinomycetes. Methods of soil analysis, Part 2: Chemical and microbiological properties. 2nd ed. Madison, WI: American Society of Agronomy, Inc.; 1982. p. 969-87. Zwahlen C, Hilbeck A, Gugerli P, Nentwig W. Degradation of the $\mathrm{Cry} 1 \mathrm{Ab}$ protein within transgenic Bacillus thuringiensis corn tissue in the field. Mol Ecol 2003;12:765-75. 